\title{
Humanimalia Roundtable on Breed
}

\section{Participants: Margaret Derry, Donna Haraway, Donna Landry, Harriet Ritvo, Sandra} Swart

Moderators: Kristen Guest and Monica Mattfeld

Event date: August 3, 2017 (Skype)

Question 1: Your work focuses on a range of domesticated animals - including dogs, horses, cattle, and chickens. Was the focus of your scholarship influenced by your personal affections or practical interactions with a particular breed or species? What difference did that make to your scholarship and politics?

Harriet Ritvo: My relationship has been with one species, Felis catus (or Felis sylvestris catus); in particular, seven of the nine cats that I've owned (or accommodated) have been Siamese to one degree or another. The only place that shows up in my work is in The Animal Estate, where I devoted a couple pages to the emergence of Siamese cats, something I might not otherwise have done. But the main impact on my work is simply the experience of having a sustained relationship with individuals who are not human, rather than the fact that they were cats, or Siamese cats. The external experience that has had an impact on my scholarly work and politics is my long interest in biology, especially evolutionary biology and zoology, and also an early - and I would say irregular - experience as a veterinary assistant to my uncle. What I'm working on now has to do with animals that are somewhere around the boundary, or non-boundary, that separates domesticated animals from animals that aren't considered to be domesticated. As with many things this is as much about the way people think and the consequences of this thinking as about something intrinsic to animals themselves.

Margaret Derry: I think I should begin by explaining the general focus of my research. My primary concern has always been with the methodology behind historical animal breeding, namely patterns of artificial selection. Therefore my response to questions concerning the meaning of "breed," "type" comes from that perspective. My personal past very definitely affected how my approaches to historical animal breeding would evolve. As a child, we bred hamsters. I also studied horse magazines on the breeding of Thoroughbreds, Quarter horses, and Arabians. I bought books on the breeding of dogs - specifically Collies. I associated breeding with art, for I was a drawer and painter from earliest childhood. In later life - after marrying and having children - I established myself as a painter, often favoring animal subjects. I sold my paintings through galleries and commissions. My husband and I bought a farm - and we 
decided to buy and breed cattle. I was ecstatic! Hands-on experience gave shape to my earlier interests by providing me with an inside understanding of breeding. The cattle also stimulated my painting - and I saw the act of breeding as one closely related to painting. It was a form of creativity, and a challenge in much the same way that painting was for me. There are very few good breeders, or even true breeders. There are lots of animal multipliers but that is not the same thing as breeding. When I returned to university in my late 40 s to do a doctorate, it was natural for me to focus on the history of cattle breeding specifically. I found my breeding experience, combined with a lifelong interest in how breeding works, had taught me how "read" documents for indepth meaning about how and why people bred animals the way they do. I could get past phrases such as "breed the best to best" - which in themselves convey little meaning of how artificial selection is actually practiced. I became fascinated with the interconnection of art and practicality/science in breeding. The old phrase "the art of breeding" both made sense to me, but at the same time made little sense, and I could see the same dichotomy in breeder language. The subject of breeding has led me into ever widening subjects: eugenics, genetics, and culture versus science. At the moment I am looking at the effects, or lack of effects, of state regulation and the pressure of animal rights/welfare organizations on breeding.

Donna Landry: I think happenstance shapes everything, especially when histories coalesce in what Donna Haraway calls "situated knowledges." Not only did I happen to prefer horses amongst all species of animal when I was growing up, but I was also fortunate enough to have riding lessons. Then I fell in with a woman who was interested in Arabians. I was an only child, fairly isolated - having been displaced from New York to Ohio - and trying to find my way, so the Arabian horse became my focus. Later, as an English major, I was very interested in questions of politics, aesthetics, and ideology. Over time, all these interests came together in my scholarship, though I didn't originally work on horses. I began, as many feminists do, with recovery work of women's writing, focusing on laboring-class women poets of the 18th century. I went on to work on the politics of the countryside in relation to increasing urbanization in the long 18th century, and on questions of empire. Like many historians who grew up in a post-1968 generation, I was interested in the ways questions about class, race, and gender shape the way we look at history. In the late nineties, as I was working on The Invention of the Countryside, it became impossible to ignore the way horses were contributing far more to changes in British culture than had been acknowledged, and I began to think seriously about both the question of agency on the part of other species and multi-species dynamics.

Humanimalia: a journal of human/animal interface studies

Volume 10, Number 1 (Fall 2018) 
Sandra Swart: I used to think - like many people - that to really understand an animal you needed to love them. In fact, Konrad Lorenz insisted that to study any species one had to love it. I began by working on dogs and horses because I know them pretty well. I've lived very closely with horses and dogs, and I've bred them, and I certainly love them. In writing animal histories, my approach was - at the time - to expose a kind of social-history school "workers" history of animals" and reclaim a hidden or silent narrative. Being an Oxford-trained social historian I was brought up on that kind of working-class recovery project in the style of E.P. Thompson, and I wanted to look at animals in a way that avoided what he called "the enormous condescension of posterity" by addressing animal agency. Having lived with animals and experienced first-hand - for good and for bad - their agency, it has always seemed quite odd to me that people even debate the issue.

As I've gotten older, however, I've found the idea of challenging condescension more problematic. When I wrote about horses they appeared in the stories I told not only as the gentle herbivore in a relationship with the rogue primate that is us, but also as the ultimate migrant laborer and foot soldier. Yet when I look at my work, I can see now that I still wrote the view from the saddle, not the view from the horse, so the condescension remains.

At the moment I am doing something totally different: writing a book on the baboon and human history that examines the long and tangled relationship between humans and baboons. Over the longue durée we have certainly had a very stormy relationship, as close family often does. It is much different than writing about dogs and horses, moreover, because it's impossible to say that you love baboons. Because they are so much like us, you can only say that you like or dislike individual baboons, but to announce that you love them would be completely mad: like announcing you love all of humanity or that you need to love people to write decent history, which of course you don't. So I would now say that historians are the curators of the human condition, but that Manichean terms like "love" and "hate" simply don't work.

I would also say, building on Levi-Strauss's idea that animals are "good to think with," that - with all apologies to George Orwell - some animals are more good to think with than others. For me, baboons are helping me think through how you can write not only the natural history but also the social history of an animal. Specifically, I think that if you can demonstrate that the history of local baboon groups is idiographic and diachronic, then you can take it out of the realm of the natural and into the cultural. And if baboons possess that slippery thing called "culture"; if we can show that their lifeways change over time and that they exhibit agency, though obviously in 
circumstances beyond their control; if we can demonstrate that their ideas are transmitted and that different generations learn to live differently because of changing environmental contexts, then I think we can actually write a social history of baboons though we have to do so using primary sources written by their enemies. This is a very fundamental difference for me, in writing about baboons rather than dogs and horses, because I'm out of my comfort zone in all kinds of ways. Like scholars who work on the classical era of ancient Rome are often struck with how these people "are just like us," that's what happened to me when I was writing about dogs and horses. But at the moment I am more like a historian who looks at the 1960s and thinks, "those people are a lot like us, but boy, they are also really, really different."

Donna Haraway: I think there is no question that in my work I'm very personally entangled. Experiences of affection and relationship have been fundamental to the direction my scholarship has taken. Even as a PhD student in Biology, I was passionate about the stuff of biology that wasn't even full organisms - it could be electron transport systems and disassembled mitochondria. I remember once telling my Women's Liberation group that I experienced an erotic attraction to the electron transport system. It was always a relationship of love and rage that really drew me in on a deeply bodily basis. And even though material I was studying was so enmeshed in corporate and military and consumerist processes, I felt that as a biologist I was responsible for somehow witnessing, and maybe something more than that. So my early work, Crystals, Fabrics, and Fields, through Primate Visions grew out of that.

Then came facing up to my relationships with individual dogs that had begun with my childhood dog, General Eisenhower. He was a rescue Dalmatian who was euthanized after he snapped at my baby brother. I remember the loss of innocence in permitting myself to be fascinated by my dog being brought to be killed. I repressed my complicity and my capacity for voyeurist sadism in that act for years, until I realized I was not alone and that the capacity for voyeurist sadism was a really important, awful part of our relationship with non-human animals living closely with us. So in a sense General Eisenhower has always been the underside of my effort to try to figure out what living closely with a companion of another species is about.

Cayenne, my Australian Shepherd agility companion, and now Shindychew (from Ursula K. LeGuin's "Paradises Lost," her name is corrupted Mandarin for "new earth"), my rescued Formosan Mountain Dog cross, have taught me what I have distilled into a kind of aphorism: if you really take relationship with any being seriously, and most certainly relationship with an animal of another species - domesticated or not - these

Humanimalia: a journal of human/animal interface studies

Volume 10, Number 1 (Fall 2018) 
animals make you more worldly, not less. I am adamant that the taking seriously of lifechanging love affairs with another animal doesn't make us smaller. It makes us bigger in really critical ways. So the Australian Shepherd Cayenne, without ever ceasing to be a dear personal friend, also ends up taking me from the Spanish rough sheep brought to the Americas, to the history of conquest, to the breeding of herding dogs of the American West, and to the extermination of Navajo churro sheep, among many other entangled histories. Taking Cayenne seriously also took me into health and genetics activism in purebred dogland, and into some animal rights advocates' opposition to all breeding of so-called purebred dogs. She took me into geriatric medicine for an aging companion, and our shared medical issues got me thinking seriously about the fact that we were both eating synthetic estrogens for female problems to do with sphincters that don't work very well when you get old. Before I got Shindychew, first dumped as a puppy in the outskirts of Taipei and then fostered in a fascinating international doghuman community linking California and Taiwan, I had no intention of engaging in international adoption. But without telling the whole story of how we got her, her birth place made me curious about other worlds. Because of her, I started furiously reading English translations of Taiwanese fiction like Wu Ming-Yi's The Man with Compound Eyes, which has two indigenous Formosan Mountain Dogs in the plot, and learning about the history and contemporary struggles of Formosan Mountain Dogs and diverse groups of Indigenous Taiwanese. Every time I end up in a love affair it excites curiosity, and because I have been educated the way I have curiosity incites scholarship. In a range of ways, I can't take a love affair seriously unless I somehow have an historical sense of what got us here and a political-ethical sense of how and to whom it matters.

Margaret Derry: I think it is really interesting how much people have talked, in different ways, about the love you must have for animals, the empathy for them. I think that is very important, and has led me to think about the ways art and beauty inform the process of breeding. Certainly, having bred cattle for 25 years I have known many, many animals, and it was their beauty as much as their personalities that blew me away: the way animals move, the way they look at you. It isn't just love; it is sense of beautiful, living other things.

Sandra Swart: I don't know. My dog is a great mother and a great dog, but she is no looker. It hasn't been beauty that has attracted me to animals, not even to horses. For me, it's a sense of like-mindedness. When I was young I fell in love with a naval officer and we lived together. He was lovely in many ways. But often I feel my dog and I understand each other much more deeply: it's more a meeting of minds. 
Donna Haraway: Can I ask you all a question about social history? It isn't questions about the agency of individual animals that really interests me, but how we might inhabit the premise that other critters actually have social histories apart from us: ecologically, developmentally, evolutionarily, historically. Their sociology has many points in historical time. So how do we take that seriously? I'm not particularly afraid of anthropomorphism. I think its fine to use various categories, as long as one tries to make them visible. But I'd like to know how you all think about doing the social history of other critters?

Harriet Ritvo: I would say that as long as you respect the complexity of the evidence, which is normally mediated through us, it should be possible. It's difficult, both because of that mediation and because there's not very much of it. There have been various scholarly attempts to speak for animals or retrieve their voices, or something like that, in which good intentions often disguise assumptions that are fairly arrogant. I think Eric Baratay ${ }^{1}$ makes the most persuasive attempt that I have encountered in his history of the non-human participants in World War I.

Donna Haraway: There's also a novel, Belka, Why Don't You Bark? by Hideo Furukawa, ${ }^{2}$ that tracks the fates, lineages, and socialities of Japanese and American war dogs that were abandoned on the Aleutian Islands at the end of World War II. I think that book does an extraordinary job of writing the dogs' social as well as individual history from a literary point of view.

Donna Landry: That's very interesting because it raises a question that subaltern studies posed, as Gayatri Chakravorty Spivak showed, but has largely been dropped that it's not that the subaltern cannot speak, but rather a question of what the hegemonic audience can or cannot hear. The complexity of the evidence is certainly highly mediated, but nevertheless within these interstices one can find something which is not a stable, fixed entity but rather something that has its own dynamic. And I think the histories of animals offer interstices through which one sometimes gets glimpses of moments of change. In my case I have only worked on horses, but I think there are moments where what I see is some kind of equine agency in terms of the horse's complex evolution with humans.

Sandra Swart: I've experimented (as Donna Landry has) with cultural histories of horses, and I think there's been some good work on this. But what's currently exciting me is seeing how baboons have a social history that is not completely or directly mediated by humans. Of course, humans make a large part of their environment, but

Humanimalia: a journal of human/animal interface studies

Volume 10, Number 1 (Fall 2018) 
they're not the ones driving the cultural change. Very briefly, there's a great example in Kenya where there was a bad outbreak of TB in the 1980s because a local village was putting contaminated meat on the rubbish dump. Among the local Baboon troop, the big males got to the meat first (by pushing and shoving juveniles and females out of the way) and they subsequently died of TB. It almost wiped out an entire generation of tough, strong primate males. When researchers came back a decade later, they found that the actual culture of that particular troop had changed. It was far less warlike, far less aggressive, and something fundamental had happened: there was a shift in the idiographic culture of that specific group. So there was a lot more mutual grooming, and there was much less violence towards subordinates, although there was still a hierarchy. It seems that this has been transmitted generationally, and while humans have had a part to play in this narrative, it's quite a small part.

Question 2: In our research we have struggled to determine a temporal point in the history of domesticated species at which "breed" becomes recognizable in its modern form. In part this has to do with the multiple meanings breed can enfold - including terms like land race, variety, population, species, sub-species, kind, family, kin, brood, lineage, stock, clan, tribe, as well as distinctions such as half-breed, mixed breed, new breed, traditional breed. There is also the problem of non-anglophone notions of "breed," which have distinct historical genealogies and meanings. How do we distill out of all this a useful focus for research?

Harriet Ritvo: In a way it's a bit quixotic to attempt to establish a clear timeline for that kind of evolution of sense; it's even hard to establish a consensus meaning for most of these terms for any particular point in time. Often if you look at the work of a single person - even somebody like Darwin who thought carefully about such things - you find him using many of these terms, but using them inconsistently. I wouldn't be surprised if we all do that. One of the problems is that all of those terms are relative, with the possible exception of species (I don't think it has a different relation to the real world than the others do, though it does have a kind of special status within taxonomy). These terms are really subdivisions of each other, rather than references to abstract categories that exist outside of what's put into them. When I started working on classification, I had a meeting with a very kind botanist who was also a very good historian of science. I asked him about categories like family - for example, whether there was anything that made a family of conifers systematically similar to a family of molluscs - and all he did was laugh, which I took as a negative. I think that response would apply to both scientific and vernacular terms. So I think the history of these terms is incredibly interesting, but I also think that attempting to pin them down - to 
look for a consensus about their meaning at a certain time, even if inquiry is restricted to a particular place or language - is probably going to be frustrating.

Margaret Derry: I agree with Harriet that a lot of these terms are simply terms, and that different people are going to think about them differently and categorize them differently. The words "breed" and "type" can be applied to any domesticated species because all result from artificial selection. Any time artificial selection is applied to a species [even populations of wild animals], studies can be done on the idea of either type or breed.

The idea of type is ancient and probably was part of domestication itself. Early artificial selection would have been used to modify a group of animals therefore cut off from the larger gene pool of their species in order to make them conform to human ideals primary among such ideals would be tameness and tractability. Inbreeding is essential to fix desirable type and that method probably plays a significant role in the combined changes seen in early domestic animals. We know now that simply selecting for these traits will alter physical appearance and genetic makeup (such as tamed foxes changing coat colour, neotony in dogs, or the reduced sized of domestic cattle from their wild counterparts). The more modern idea of type arose throughout the world and related to fixing desired characteristics in animals. While I focus on Europe and North America in my research, I think the situation in other areas differs little from that in Europe. Type always meant reproduction of animals true to type - that is, at least some consistency and generally through inbreeding. "Like begets like" being the motto for how artificial selection would be practiced. There were distinct types of dogs, horses, sheep, and cattle through Europe probably at least as far back as Roman times. These types tended to be restricted to local environments, but there was considerable movement of animals even at that time. The Romans took chickens with their armies throughout their empire. Horses and cattle were imported from the Netherlands to Britain and continental Europe by the Middle Ages - and these animals modified the types found in their new homes.

The idea of breed is relatively new, compared to domestication, in the course of human/animal history. The idea of breed - that is, before the advent of purebred breeding - was restricted to stock bred and raised by either royalty or nobility. The idea of "breed" dates back at least 2000 years, but gained in strength after 1600. That is true of Europe, but also the Middle East and China. Thoroughbreds, King Charles Spaniels, Lipizzaner horses, Arabian horses, Pekinese dogs, are all examples from diverse geographic areas. "Breed" was the prerogative of animals kept and bred by the

Humanimalia: a journal of human/animal interface studies

Volume 10, Number 1 (Fall 2018) 
nobility and royalty. Type referred to the vast majority of animals of different species under human control - and type came to relate to specific geographic locations. The modern idea of breed has become irrevocably interconnected with purebred breeding, a system that arose in England in the early 19th century, and subsequently spread around the world. It is difficult to overestimate the impact purebred breeding has had on artificial selection practices since that time on a world-wide scale. Purebred breeding democratized the idea of breed, the earlier preserve of the upper classes, and in doing so has become so pervasive that other and older approaches to artificial selection often seem hidden.

Purebred breeding is based on two primary concepts: the keeping of public pedigrees as opposed to private records, and a breeding principle based on selection by ancestry breeding. At its heart is the use of a show system to establish levels of excellence. Pedigree keeping proved to have huge implications - primarily related to marketing - but it supported ancestry breeding too, a methodology that in its mature form carried with it many complex ideas relating to the convergence of genetics, purity, and quality. Succinctly, pedigrees linked breeding culture with economic worth.

When pedigree-keeping, with its effect on marketing and breeding methodology/culture, became intimately tied to a show system, the basic dynamics of purebred breeding had been formed. Show-ring dynamics under purebred breeding developed more significant implications over the 19th century, and came ultimately to be almost the raison d'être for breeding by the method. Pedigrees were vitally interconnected with this structure because they regulated which animals could participate in the show system. Since pedigree standards governed which animals could compete in shows, they became intimately tied to the potential marketability that showsuccess provided.

While purebred breeding promoted the idea of purity, it is important to remember that simply saying purebred breeding was about purity and elitism is just too simple. The idea of "purity" was irrevocably attached to the concept of consistency of type and the ability to breed truly. The animal was guaranteed "pure" - meaning it would stamp its type on its progeny, and the animal was effectively certified to do so via pedigree status. Inbreeding was the method used to fix type. The importance of these features cannot be overestimated when one looks at the compelling market force this provided - especially in long distance travel. The animal would breed as truly in North America as in Britain, was the belief. This did not prove to be the case in southern hemisphere countries like South Africa - causing many people to question the effects of environment on genetic structure. The cultural significance of "purity," as opposed to 
its breeding significance, comes from the method's inheritance of Thoroughbred horse breeding philosophy. Thoroughbred ideas of purity of the blood dovetailed unevenly with Robert Bakewell's principle of inbreeding. Inbreeding became a stamp of purity. Bakewell did not believe in purity and Thoroughbred horse breeders did not believe in inbreeding.

One domestic species that continued for some time to be dominated by breeding for type was the horse. The Thoroughbred, for example, would combine its particular methodology for breeding with a veneer of purebred breeding but it never relinquished its historical approaches to breeding that had emanated from the ideas of royalty and nobility in the late 17th century. The heavy horse - Shire and Clyde - were not "purebred" until near the end of the 19th century. The French Percheron only became "purebred" because Americans forced French breeders to adopt the system for marketing reasons. The older horse types found in North America - the Royal Georges, for example, and the various lines of trotting horses - first came under what was known as the standardbred system (the selection of breeding animals and their pedigree registration are driven off their ability to meet a standard and to pass a test based on that standard), but this too would ultimately be overlaid with purebred breeding. The horse has retained principles of breeding that relate to type more than breed - the standardbred system being type breeding in its modern form - witness the Dutch Warmbloods. The Standardbred system does not pedigree animals solely on the basis that both parents are themselves pedigreed. And there has been a general move within horse-breeding circles back to the idea of type. Hard to call this simply cross breeding, because the animals are designed to consistently fit standards of type and to breed truly to that type.

As far as I can see, because of the pervasiveness of purebred culture in any breeding, a clear understanding of how purebred breeding works and worked historically is essential in order to see what breeding concepts did not arise out of purebred breeding. It is then possible to see the historical overlay of other approaches to artificial selection and the influence of regional culture on how breeding proceeds, even within the structure of purebred breeding itself. The idea of type did not always die, nor did regional and cultural approaches to artificial selection become completely obliterated by the standards of purebred breeding. It has remained strong in certain horse breeding circles, such as European Warmbloods, even if an overlay of purebred methodology infiltrated the breeding of these horses. The overlay of purebred breeding in Arabian horses has not obliterated the dictates of a different system relaying on strains and female lines. I think the concepts of breed and type can be useful for researchers if they

Humanimalia: a journal of human/animal interface studies

Volume 10, Number 1 (Fall 2018) 
can distinguish one from the other, and bear in mind that the artificial selection of domestic animals is the key to all this. This is what changes animals, and if we understand what those practices are and how they change over time you can begin to see a complete overlay of systems driven by cultural inlays and changing attitudes what's good, what's bad, and so on.

Harriet Ritvo: Can I just mention the big elephant in the room that is not in the question, and that is why domesticated species are called species at all? The reason for doing it is completely different than the reason for identifying species in any other context.

Donna Landry: Well we are all in agreement that breed is a construct like race is, that these terms are most certainly relational, and that species has a special status. It seems to me that historically the overlapping use of "breed" enfolds a range of meanings beyond what the nobility produce - as in what the people in a family produce, and what people in a geographical locality produce. In England we find English landowners still speaking of their own personal breed - as in the horses that they breed - into the 18th century, and then that begins to overlap with something that seems to me to have more of an ethnography mapped onto it as it emerges. And then this is combined with the notion of how these creatures behave and what their characters are like. There is type, but it is taken from character as well as visible type. So there's a long earlymodern period between 1550 and 1850 when these terms are coexisting. But increasingly after 1750, and certainly as Margaret says, in the 19th century following the establishment of the General Stud Book in 1791, the question of purity becomes an issue and the notion of breed becomes something much more associated with nation. And I think this development is important in the development of anglophone (that are also sometimes anglophile) terms as culturally specific. In my work, I've been trying to understand Turkish and Ottoman ways of thinking about questions of breed. In Turkish the term "cins" refers to a very capacious concept melding genus, species, class, race, kind, varieties, sex, gender, purebred, and thoroughbred. And then there's "1rk," which is race or lineage. In Turkey today there are only two kinds of horse which rate as cins: the Ingiliz (English) Thoroughbred and the purebred Arabian. Irk might include any number of kinds and all sorts of Anatolian breeds, all of which have their own specific histories and locations. Now I tried to map this distinction onto Ottoman history, where one of the few sources we have is Evliya Çelebi's Seyahâtnâme. ${ }^{3}$ Evliya Çelebi never speaks of "Turkish" or Turcoman horses, as 17th-century Europeans did; he only gives us particular kinds of horses from near the Caspian Sea or Central Asian horses that western travellers would have called Turcoman - the "Nogai" or the "Karaçubuk" ("Black Rod"). His favorite is the "Küheylan," which might occupy the same category 
as the "Arab thoroughbred," or indicate the specific strain of "küheylan" as still used by the Bedouin today. There is a question here about the difference between cins, what gets to count as something that is so legendary as to be almost a species unto itself, and a mere $t r k$ (race). In the west, the problem of breed as "legend," in this sense, is situationally specific, but something that I think has to do with the rise of nationalism insofar as breed today commodifies and protects type via registries, dedicated organizations and other institutions.

Sandra Swart: Because of South Africa's very particular and racialized past the question resonates with me in terms of "breed purity." I've long been tempted to write a book called "Mongrel Nation: A History of South Africa," because of the politics of breed and the particular route it took here. Obviously you all have very usefully discussed the different meanings and concepts behind breed and its etymology - even a kind of taxonomy between these related terms. In Afrikaans, however, breed is "ras" (race) and that is exactly how it translates: crudely, coarsely, bluntly. And that's the way it's worked historically. When South African breeders talk of breed there's often a rhetorical overlay of authenticity and purity that actively tries to mask any hybridity. But ironically, hybridity is the most authentic South African dimension of the enterprise. Certainly from a teleological perspective, animal breeding is the final place where ideas about purity of breed and openly eugenic discourse can be freely embraced, alongside classism and even sexism.

What is useful is the way these associations quite usefully open up otherwise hidden debates. I don't need to rehearse South Africa's history, but you all know that an exceptionally virulent strain of racism has run unchecked since the early 20th century under the auspices of racial science, accompanied by a morbid fear of miscegenation perhaps unparalleled elsewhere in the world. Miscenogenophobia really is the fear of the so-called half caste, of the mongrel, of the impure, and in South Africa it signals fears about sexual relations between white people and Africans - though in actuality the whole white polity is built on hybridity. The concept of breed really leads us to the continued entanglement of human and animal.

If you go right back to the original Dutch Settlers that have long claimed a Purity and superiority of breed, for example, you find there was extensive interbreeding between the Dutch settlers and the local Khoisan women - not just sexual adventures and coercion, but also marriages in the early years of settlement. This was conveniently forgotten by the Apartheid state when they outlawed interracial mixing, but by the late 17 th century three-quarters of all children of slaves had white fathers. So there is the

Humanimalia: a journal of human/animal interface studies

Volume 10, Number 1 (Fall 2018) 
creation of a mestizo class that has been denied in the history books. And this doesn't go away: ideas about genetic and cultural purity persist not just physically but also culturally. Here, this idea about an essentially organic culture of particular breeds has offered a useful fiction for ordering and then policing the South African state. Yet, there's a very porous boundary between the Apartheid state and human classification that shows its face in the centralized State's involvement with animal breed associations. In the 1910s and 20s it became increasingly obvious that a lot of white Afrikaans farmers were being out-competed by African farmers. To address this, the state kicked into high gear - not only aggressively enforcing segregation legislation to protect the purity of the white race, but also, at exactly the same time, talking about the need to protect existing animal lineages to ensure they were not contaminated or diluted by African stock.

There is a very famous quote by Louie Botha, the first president of South Africa, where he says that if you breed an Afrikaner cow with a Friesland bull that the Afrikaner cow will always be contaminated: she will always bear the imprimatur of this first mating and her children will also be polluted even if she then breeds with a pure Afrikaner bull. He particularly mentions Afrikaner cattle because the Boers had an almost quasimystical relationship with this breed, believing that both cattle and men had come from authentic or tougher stock than was owned by the Khoisan people and other aboriginal groups. The belief was that these qualities had evolved over time, making cattle and men stoic, noble, enduring, powerful, robust and masculine - and this is exactly how Afrikaner culture brokers were starting to describe the Afrikaner people. In fact, the story is so entangled that it goes right back to the first great trek in the 1830s, when Afrikaners left the cape and came to the hinterland to found independent Boer republics. Here the myth is that all the wagons were drawn by Afrikaner cattle. Both cattle and men were seen as breeds that had almost been destroyed by the scorchedearth policy of the British, and the idea was that Afrikaner should rally round this breed that had being so good and staunch for the Afrikaner people. Over time a breed standard developed, and it's now the most popular beef cattle in the country. It looks entirely different, of course, but while the cow has changed radically the myths of breed purity have stayed the same.

Donna Haraway: There are so many ways to enter this question. The last line of the second question asks how we distill a useful focus for research. Obviously, the answer depends on the situated historical/social/biological settings that frame the research. As everyone has already said, the terms themselves are relentlessly relational - so I want to start thinking about this, as Sandra has, from the point of view of being a citizen of a racist white-settler colony. Though there are many of these, with different histories, 
questions about purity and mixing nonetheless remain on the agenda of daily life and political struggle, via questions about who lives and who dies. For both animals and people you cannot separate these issues of political struggle. For example, one can't go to an off-leash dog beach in California - where the prestige of having and owning an identifiable non-breed, so-called rescue dog (particularly of a pit bull variety) is high without thinking about the implications of race and class profiling. The death rate of both so-called Pitbulls and Chihuahua crosses is astonishing And I think of my Formosan Mountain Dog cross, Shindychew, and I know that there have been efforts, on the one hand, first to exterminate so-called primitive dogs, and afterwards, on the other hand, to collect the remaining "pure" dogs into a closed breed with a standard, but with two competing breed groups in Taiwan. All this while the death rate of mixed dogs escalates, and the situation of free-roaming dogs in Taiwan becomes less and less viable. So I'm really interested in these questions of mixture and purity in relation to the state, and particularly to histories that involve colonization; interested in understanding what happens between animals and humans in relation to questions of kind.

I remember once being asked by the editors of a Marxist dictionary if I could write an account of gender. I had to pay attention to five languages, including Chinese, Japanese, German, French, and English. As soon as I was thrown to geschlecht in German my entire ability to write that article changed completely, because I was thrown via gender into breeding. For me at this moment, the current question is about kin/kind in relation to family. There are more than seven and a half billion human beings on the planet today; most likely by the end of the century over 11 billion human people will be alive, barring widespread eco-social collapse. ${ }^{4}$ Closely coupled with high-consuming wealthy humans, meat-producing and other extracted, exploited animals increase in numbers beyond bearing. Given the extraordinary over-numbering of the planet since World War II for both humans and non-humans, I'm concerned with this even as I'm also aware that talking about it immediately brings up charges of racism. You cannot talk about surplus numbers without being told, usually from someone screaming at you from the audience, that you are no longer a feminist, or that you are neoliberalist and racist to the core. Moreover, the minute you talk about human numbers there are tight associations with the breeding of both crops and animals. The industrial breeding of food plants and animals is absolutely fundamental to the socio-ecology of Capitalist expansion after World War II, and you can't navigate this terrain very well without being called a racist.

Personally, I'm committed to "making kin not babies," a feminist anti-racist project. So I'm extremely interested in non-biogenetic concepts and practices of family and kin

Humanimalia: a journal of human/animal interface studies

Volume 10, Number 1 (Fall 2018) 
making, which certainly include critters called pets, but also register that the overpopulation of animals called pets is part of the over-numbering that I'm talking about. Blaming poor human beings for over-numbering, while the rich drive environmental destruction and injustice, as well as refusing to make kin outside biological or other conventional kinds of relatedness, whether with human migrants or non-human exploited or exterminated beings: all of this and more inhabit my nightmares. So I'm really interested in what constitutes multi-species environmental justice. And I think that this needs to be expanded outside the premise of human exceptionalism by recognizing that situated human histories are always multi-species affairs, and are always fundamental to these matters. This means that I and others really need to think about the implications of language, such as population, kind, family, clan, brood, lineage, and the rest of it; because on a global basis, things like the making of kin-like relations between critters are as absolutely fundamental as (and related to) the question of climate change. Right now, we also have to deal with our inability to talk about all this because people like me are afraid to be labelled as racist, just as certain Christians are afraid to talk about climate change because God couldn't have done that to His children. I actually think that feminists and so-called progressive people like me are afraid to talk about non-biogenetic family making or kinship making in relation to complex, differentiated human numbering. And I'm finding using the word "population" almost impossible for reasons Michelle Murphy makes plain in her wonderful new book The Economization of Life, ${ }^{5}$ but there's not a good synonym. That's what breed comes to for me: it has everything to do with being the child of a whitesettler racist state.

\section{Question 3: What questions about breed do you think are most pressing now?}

Harriet Ritvo: I was going to say maybe pressing wasn't the right word; but having heard what Donna just said I revise that, and I have to say that I haven't heard such an eloquent formulation of the straitjacket in which we inside the bubble find ourselves placed. So thank you Donna!

Donna Haraway: For being screamed at repeatedly ....

Harriet Ritvo: Well among other things, yes. That is to say it is easier to just shut up.

Donna Haraway: And I think shutting up is an extra-ordinary failure of morality as well as scholarship and solidarity. We need to risk being wrong out loud and open to each other on very hard issues. 
Harriet Ritvo: So, here are some things that people might start to think about now. In a way, and as all of you have suggested, it's the analogy between the breed-oriented rhetoric having to do with animals and questions of race having to do with humans. It is always a bit easier to let things slip out, or to say things unintentionally, when you are talking about other animals than when you are directly talking about people. But then some things just to do with breed in a more restrictive sense might be interesting to examine, such as the motivations that people have and still have for creating (or repackaging) kinds of animals. Sometimes it's actual physical manipulation, but there always seems to be a value to the establishment or validation of difference that I think is worth considering. It's interesting to look at arguments within breeds about standards, especially - and this has been raised before - standards that integrate concerns with "excellence," in whatever sense that is understood by breeders, with humane considerations, such as whether or not animals can breed or breathe without too much inconvenience or distress. I should say I always find it interesting to think about the way that people construct the histories of the breeds that they are most fond of. My sense is that most of those constructions are based heavily on fantasy. This kind of thing has been explicitly demonstrated with regard to the thoroughbred horse, because it has such a long history and a lot of attention has been paid, but it is much more widespread. I have witnessed an aficionado of Pharaoh hounds claiming that the modern breed is descended directly from the dogs who might have lived in King Tut's kennels. The last thing that I would throw in is how emerging technologies of genetic analysis and genetic engineering will affect (or has already affected) the breeding of domesticated animals.

Margaret Derry: What I was going to say was something like what Harriet said towards the end. I would say understanding DNA technology and how it interfaces with modern breeding is critical right now. The resilience of culture in animal breeding remains remarkably strong, and trying to understand why is important.

DNA technology can help us save breeds from the genetic defect overload that inbreeding has induced. The trend to cross breeding seems to have partially resulted from genetic defect issues, but the movement has not alleviated the problem. First, the animals used in the programs pass on their genetic problems, and second, there has been a tendency to make the cross-breds conform to the idea of "breed." They are just new breeds. Modern technology can go a long way in correcting at least some of these difficulties, but not before the breeders alter their breed regulations and standards. This is where state regulation of breeding and or animal rights organizations can fit in. A modern defect in Shorthorn cattle is not regulated by the breeders in North America,

Humanimalia: a journal of human/animal interface studies

Volume 10, Number 1 (Fall 2018) 
and it can be with DNA testing. Cattle carrying the recessive defect are pedigreed by the breed associations. At the moment organizations like PETA seem unaware of the problem, but some Shorthorn breeders wonder when they will be forced to resist pressure from such groups, even if the state does not interfere. In contrast to that situation, pressure from animal rights groups made the breed society in Britain forbid the registration of cattle carrying the defect. Another example of international breeder organization approaches to defective breeding in relation to pressure from the state or animal rights groups can be found in Collie breeding. The merling gene, which dilutes color, can cause serious defects if merle to merle dogs are interbred with each other. There is no regulation set by Collie breeders against merle to merle breeding. Double merles can be pedigreed, in spite of rising criticism from some dog breeding circles. The situation is different in Europe. The European Convention for the Protection of Pet Animals [a treaty of the Council of Europe] sets out standards of breeding which are designed to stop the ongoing perpetuation of genetic defects. Breeding of merle to merle is forbidden. Collie breeder organizations are more or less forced to adopt these standards. In Britain, animal welfare groups forced the Kennel Club to stop registering puppies born from merle to merle mating. Only in the US and Canada can such puppies be registered. Double merles are used for breeding and showing as well.

DNA technology can be used to preserve breeds threatened with extinction. It can be used to introduce aspects of wild cousins' genetic makeup to the DNA of domestic animals in order to improve their health and performance in geographic areas that challenge their wellbeing. The history of breeds and their background genetically speaking can be better understood with the use of DNA technology. This would not only provide fascinating historical information but the situation could well help undermine cultural myths about breeds which lay the foundations for beliefs that are unfounded, and which promote unwise decisions concerning breeding practices and elitist attitudes towards other breeders and breeds. To me it is understanding how this technology can be incorporated by breeders into breeding programs, because there really isn't much movement that way now - at least not from my experience in breeding and breed organizations.

Donna Landry: Having discovered that there are a lot of historians, particularly those working on court studies, who haven't really noticed horses before, I think that making the panoply of animal studies available to them in ways that would be useful is something worthwhile that I've been working on. This has brought me to thinking about breeds in terms of history, again picking up on what others have mentioned. I'm interested right now in constructions of nobility, in particular dynastic associations. Here, as in the case of South Africa, transnational networks and hybridity in relation to 
pure-breeds seem to be really important. I'll just give the example of the Lipizzaner: very clearly a product of the Habsburg Dynasty and the Austro-Hungarian Empire, the foundation sires for that breed included a Spanish horse from the Royal Danish stud, several Neapolitans - which is to say Italian horses with Spanish breeding, two Kladrubers - which are identified with Czechoslovakia but also have Spanish breeding, and then finally, at the beginning of the 19th century, a purebred grey Arabian from the Syrian desert, representing the desire to go back to purity. So what could be more mongrelized, yet also become so fixed as an iconic breed type, than to become a breed that became a victim in the Second World War, in need of rescue by General Patton, and in the end to inspire perhaps the only historically-grounded Disney film ever made (The Miracle of the White Stallions from 1963)? So the story of the Lipizzaner has been appropriated in any number of ways, including by the Slovenian poet Edward Kocbek, who writes: "It is good, when the day shines, / the Lippizaners are black foals / And it is good, when the night reigns, / the Lippizaners are white mares, / but the best is, / when the day comes out of the night, / then the Lippizaners are the white and black buffoons, /the court fools of its Majesty, / Slovenian history." ${ }^{6}$ I think one of the things we need to keep track of is how ideology informs questions of sovereignty - I'm thinking here of Margaret Derry's work on Arabian horse breeding and the disputes in recent decades over the U.S. versus the rest of the world. All of this is bound up with the sorts of things Donna Haraway was talking about, which is to say questions that are difficult to address but which have to be addressed; in which whole institutional histories of racism cannot simply be left to one side. Questions of multispecies justice or multi-species lens are not simply and should not simply be the preserve of rich, white people.

Sandra Swart: That's very helpful; very interesting. South Africa also got some Lipizzaners after World War II, Donna, and they have their own local mythography surrounding them. But about the question of what about breed is most pressing now? Well, I think the political relevance of breeds is clearly an important question. I've already spoken at length about Afrikaner cattle and questions of breed purity, but another important question concerns the ownership of indigenous breeds. Indigenous breeds are going to be more important because of the question of climate change. South Africa is becoming hotter and hotter; we are in the midst of an unprecedented drought, and it will get worse. As time goes by, I think it will be an important political question as to who owns the right to indigenous breeds that are better equipped to survive drought; and who should be profiting from these particular breeds. If we revert to them, and at the moment some genetic reserves are held by the state, I put it to you that Aboriginal Organizations should be seeing at least some of that action.

Humanimalia: a journal of human/animal interface studies

Volume 10, Number 1 (Fall 2018) 
I think the second thing is the practical relevance of breeds, and here many things come to mind but one is the idea of banning Pitbulls. This has relevance in South Africa, where from time to time the press and the state raise the idea of banning Pitbulls. This happens because many of them are owned by gangs and there's quite a lively underground trade in dog fighting. But there have been many cases recently of children attacked by so-called Pitbulls, when in fact it is not just gang-owned Pittbulls, but Pitbulls who whose owners proudly keep the lineage pure. This is something we are going to need to think about in global as well as a local contexts, and I think historians who tell a longer story will be useful here.

The third thing is the money side of breed, which suggests how breeds suddenly come to matter in ways you would not expect. With Zimbabwe (because of the despot Mugabe) going into financial recession many people are facing starvation this year, and the economy is ruined. But for the first time, young, upwardly-mobile, black African Zimbabweans are getting interested in dog breeds, and dog breeds have become a consummate consumer signifier - a status symbol of upward mobility. At the same time, purebred breeding offers a way to make money in difficult times because it's fairly easy to breed a dog, and it's a fallback position for many young black Africans who aspire to the middle class. I find the trend towards importing dogs like Bull Terriers, Rottweilers, and German Shepherds very interesting, as is the case of the black Boerboel - a large, Mastiff-like dog that has its own invented history in South Africa. The Boerboel was supposed to be either from a native breed or Mastiffs brought to the country by the first Dutch settlers, so in a lot of ways its story parallels the one told about the Afrikaner cattle: it's a dog that loyally served the Afrikaner people, going with them into the interior to conquer and tame the wilderness, and that consequently became better adapted, tougher, and better at survival, just like the settlers. It's a narrative that's very familiar in the white secular state, especially under Apartheid. But just recently something very intriguing has happened. The Boerboel is largely a brindle dog, but often in a litter of puppies a solid black puppy is born - just as in many white African households a dark child is occasionally born because the Afrikaner people are genetically about 7\% non-European. In 1983, when they first invented the Boerboel breed standard, black puppies were expressly excluded. But today the black puppy is back with a vengeance, and its vogue seems to be largely about money. An ordinary Boerboel sells for about 5000 Rand, but a black puppy can now sell for between 15000 to 130000 Rand when exported to Americans. What happened as a result is that the state has started intervening, saying that unless purebred status is established breeders can't export these animals; this has created an uproar in the dog breeding world, so much so that some are registering their dogs in the neighboring state of Namibia. Others are 
saying - as they did under the Apartheid regime - that the Boerboel registry should maintain the current taxonomy and sneak the puppies in as "Ultra brindle." Still others are advocating the scientific route offered by DNA testing. This is where, contra Margaret's experience, I have seen breeders embracing technology. In fact, the Boerboel breed Society can now legally undertake spot DNA tests of any Boerboel dog.

The final point I want to make, aside from political relevance, practical relevance, and financial relevance, is the relevance breed has to living, breathing animals. There are many examples we can choose, but I find interesting the invention of the canis Africanis, the so-called African land race or breed. There was a wonderful myth that there is this pure, untouched African breed going back 10, 000 years. If you look at it, it's the kind of dog you would find if you mix a lot of random breeds together and added a large dash of Greyhound blood, which Africans prefer for hunting purposes because of the speed. But once that dog was invented as a canis Africanis, it got the stamp of authenticity and autochthony. Such claims to breed purity have led not only to many middle-class South Africans owning what is essentially a mongrel, but to them treating it with pride. This phenomenon has fundamentally changed the lives of many, many mutts.

Beyond domesticated animals, one of the earlier speakers mentioned the blurring lines between domestic and wild animals, and I think we see this very nicely in Africa where the Department of Agriculture has unilaterally reclassified 12 Wildlife species from species to breed. It's fascinating to me, not only because it commodifies, but also because it domesticates wild life, regulating it under the state's Animal Improvement Act. So things like Wildebeest and Impalas can now be genetically modified or manipulated just like domesticated animals. Any of these animals can now be changed "in the interests of the Republic," and I think this is going to change these animals' lives, because there is a new trend towards breeding for the "Exotic Local." So breeding for the "strange familiar" is resulting in white Springbok or purebred black Impala. Such breeding programs fundamentally change the quality of an animal's life, as well as altering their susceptibility to various local diseases. I think the Department of Agriculture has not thought this through and they need to be challenged by historians who can offer a different narrative on this subject.

Donna Haraway: I think I will take a particular angle on this question, prompted by the title of a recent collection, Arts of Living on a Damaged Planet. ${ }^{7}$ I want to think of breeding in relation to the cultivation of the arts of living well with each other on a damaged planet - without a sense of apocalypse and the rest of it, but with a real alertness to

Humanimalia: a journal of human/animal interface studies

Volume 10, Number 1 (Fall 2018) 
urgency. I have always been maybe too ready to take sides, so that my scholarship is always under a kind of tension with advocacy of different kinds. I try to keep the tension honest, and I try not to be an idiot about it, but taking sides is important to me. So, for example, I'm very interested in alliances with some purebred dog breeders and not others; and I am against some animal rights advocates' opposition to all breeding of, for example, dogs and horses. I think it is important to take up the histories of breeding, the historical situatedness, the non-purity of it all, and to be for some practices and not for others, and to try and clarify with each other how some of this clearly relates to contemporary technological issues. I'm also interested in what kinds of breeds - plant, animal, and microbial - need to be cultivated to support the arts of living on a damaged planet. And I'm interested in experimentations related to heat tolerance and migration issues, and in questions of genetic mixing, and what that does to protection status. Generally, I feel a need to be part of the ongoing struggle over who lives and who dies, and in thinking about the historical basis of this. Everybody today has given extraordinary examples of why the history really matters, and all of this for me is in relationship to questions about extinction. I remember walking with my aged Australian Shepherd purebred at the John Day National Monument, which preserves a 65 million year record of the evolution of mammals, including the dog family. This history has produced vast radiations of dogs on the North American continent, particularly in that area of Eastern Oregon. And thinking about all the dogs that were and are on the day we walked through the rocks led me to think about who lives and who dies, bringing extinction into the matter. Contradictions and complexities abound. So we have to find a way to oppose turning wildlife into an alternate breed so they can be hunted in a barrel, but also not be purists about genetic interventions with wildlife. We have to support Indigenous property rights in animals, while opposing the commodification of animal flesh. Clearly the contradictions are endless; and I suppose if I have any role to play in the scholarship of this, it is trying to figure out a way to narrate the contradictions so we can be part of the struggle. So we can cultivate the capacity to respond, what I call response-ability.

Margaret Derry: I think running through all of these things is the issue of purity: what purity means. But fundamental to all we talk about with respect to domestic animals, and increasingly to wild animals, is their marketability. This is where purebred breeding drastically changed things; it is the reason why these ideas about purity became global as animals moved from the countries they were bred in, to locations around the world. There was money in the idea that consistency of type had to be preserved, and there still is money in that. So I think the vast global market for animals is very much part of the story. 
Donna Haraway: I feel like that really needs emphasizing: we are really hitting it with this question of breed, right smack in the middle of all of the worlding processes around us, even this ecological system, this world-ecology in Jason Moore's terms, ${ }^{8}$ called capitalism. And not in some simplistic way.

Us: Any final thoughts?

Donna Haraway: Yeah. I love my dog.

\section{Notes}

1. Eric Baratay, Bêtes des tranchées. CNRS, 2013.

2. Haika Soru, 2012; http://www.haikasoru.com

3. An Ottoman Traveller: Selections from the 'Book of Travels' of Evliya Çelebi, trans. Robert Dankoff and Sooyong Kim. Eland, 2010.

4. Adele E. Clarke and Donna Haraway, eds. Making Kin Not Population (Prickly Paradigm Press, 2018).

\section{Duke UP, 2017}

6. Edward Kocbek, "The Lippizaner," from Embers in the House of Night, trans. Sonja Kravanja (1977); the poem ends: "Those who don't know how to ride a horse, / should learn quickly ... /motors tend to break down,/elephants eat too much,/our road is a long one,/and it is too far to walk." http://www.poetryinternationalweb.net/pi/site/ poem/item/5169

7. Anna Tsing, Heather Swanson, Elaine Gan, Nils Bubandt, eds. Arts of Living on a Damaged Planet (U Minnesota P, 2017).

8. Capitalism in the Web of Life. Verso, 2015.

Humanimalia: a journal of human/animal interface studies

Volume 10, Number 1 (Fall 2018) 